\title{
Polymorphisms at 1q32, 8q24, and 17q22 loci are associated with nonsyndromic cleft lip with or without cleft palate risk in the Slovak population
}

\author{
Jan Salagovica, Lucia Klimcakovaa , Marianna Zabavnikovab , Jana Behunovac,d, Terezia Hudakovaa , Jozef Fedelese, \\ Agata Molnarova ${ }^{e}$, Ludmila Podracka,ff
}

\begin{abstract}
Background. Nonsyndromic cleft lip with or without cleft palate (nsCL/P) is the most common orofacial birth defect with an aetiology involving both genetic and environmental factors. Genome-wide association studies (GWAS) have identified several genomic susceptibility regions for nsCL/P. In the present study, the three well established single nucleotide polymorphisms (SNPs) identified by GWAS (rs987525 at 8q24, rs7078160 at 10q25, and rs227731 at 17q22 loci) and one SNP identified by candidate gene study (rs642961 in IRF6 gene at 1q32 locus) were analysed for an association with nsCL/P in Slovak population.

Methods. Nucleotide variants were genotyped in $165 \mathrm{nsCL} / \mathrm{P}$ patients and 326 unaffected controls. All variants of interest were genotyped using high-resolution melting analysis after real-time PCR.

Results. We found significant differences between patient and control groups with respect to the allele and genotype frequencies for the SNPs at the 1q32, 8q24, and 17q22 loci. SNP at the $10 q 25$ locus showed a trend toward association with nsCL/P risk.
\end{abstract}

Conclusions. The results suggest that SNPs at the 1q32, 8q24 and $17 q 22$ loci may contribute to the nsCL/P risk in Slovak population.

Key words: nonsyndromic cleft lip with or without cleft palate, genetic association studies, single nucleotide polymorphism

Received: November 15, 2016; Accepted with revision: March 16, 2017; Available online: March 30, 2017

https://doi.org/10.5507/bp.2017.009

${ }^{a}$ Department of Medical Biology, Faculty of Medicine, PJ Safarik University in Kosice, Slovak Republic

${ }^{b}$ Department of Plastic, Reconstructive and Aesthetic Surgery, LP University Hospital, Kosice, Slovak Republic

'Department of Paediatrics, Faculty of Medicine, PJ Safarik University in Kosice and Children's University Hospital, Kosice, Slovak Republic ¿Institut fur Medizinische Genetik, Medizinische Universitat Wien, Austria

eDepartment of Plastic, Reconstructive and Aesthetic Surgery, Faculty of Medicine, Commenius University and University Hospital, Bratislava, Slovak Republic

${ }^{f}{ }^{{ }^{s t}}$ Department of Paediatrics, Faculty of Medicine, Comenius University and Children's University Hospital, Bratislava, Slovak Republic Corresponding author: Jan Salagovic, e-mail:jan.salagovic@upjs.sk

\section{INTRODUCTION}

Nonsyndromic cleft lip with or without cleft palate (nsCL/P), the most common type of orofacial clefting, is one of the most frequent birth defects. Prevalence of $\mathrm{nsCL} / \mathrm{P}$ varies widely among different world populations, generally with Asian and Amerindian populations appearing to have the highest frequencies (approximately 2/1,000 live births), European-derived populations being intermediate (approximately 1/1,000 live births), and African populations the lowest (approximately 0.4/1,000 live births) (ref. $\left.{ }^{1-4}\right)$.

$\mathrm{NsCL} / \mathrm{P}$ impose a large burden on the health and health-related quality of life, and represent a challenge to patient care 5 . The aetiology of nsCL/P is multifactorial, including both genetic and environmental components ${ }^{6}$, though the specific genetic and environmental factors remain largely unclear. A variety of genetic approaches have been used to identify genes and pathways underlying nsCL/P. Before 2009, only one gene (interferon regulatory factor 6, IRF6) had been identified with a sufficient degree of consistency across studies, thus being considered a true $\mathrm{nsCL} / \mathrm{P}$-associated gene ${ }^{7-9}$. Association of $\mathrm{nsCL} / \mathrm{P}$ with single nucleotide polymorphism (SNP) rs642961 in the IRF6 gene located at chromosomal region 1q32 was confirmed in candidate gene and genome-wide association studies (GWAS) of European-derived populations ${ }^{10-11}$. The GWAS in Europeans also identified one of the most robust nsCL/P susceptibility loci at chromosome 8q24 (ref. ${ }^{11-13}$ ), principally tagged by SNP rs 987525 . Additional significant GWAS signals in the European populations ${ }^{14}$ were detected at loci 10q25 and 17q22, SNPs rs7078160 at $10 \mathrm{q} 25$ and rs 227731 at $17 \mathrm{q} 22$ being the strongest susceptibility markers.

In the present case-control study, four SNPs (rs642961 at 1q32 (IRF6 gene), rs987525 at 8q24, rs7078160 at $10 \mathrm{q} 25$, and rs227731 at $17 \mathrm{q} 22$ ) that have been reported to be significantly associated with $\mathrm{nsCL} / \mathrm{P}$ in European populations were analysed for an association with this birth defect in Slovak population. 


\section{MATERIALS AND METHODS}

\section{Study subjects}

Patients (165 Caucasians) were recruited at the Departments of Paediatrics and Department of Plastic, Reconstructive and Aesthetic Surgery in Košice and Bratislava. Cases with congenital anomalies or developmental delays that could reflect a malformation syndrome other than nsCL/P and patients with syndromic orofacial clefts were excluded.

The population control group was composed of 326 unselected and unrelated newborns (Caucasians) from the University Hospital in Košice. The newborns were free from congenital anomalies and had no family history of clefting or other major congenital anomalies. All parents signed an informed consent. The study was approved by the ethics committees of the contributing centers.

\section{Genotyping}

Genomic DNA from blood was extracted using Wizard Genomic DNA purification kit (Promega Corp., Madison, WI, USA). Genotyping of 1q32 rs642961, 8q24 rs987525, 10q25 rs7078160, and 17q22 rs227731 was performed by real-time PCR in the presence of unlabeled probe and LCGreen Plus dye with subsequent high-resolution melting analysis (HRMA) using Eco Real-Time PCR System (Illumina Inc., San Diego, CA, USA). For all four SNPs the PCR was performed in a total volume of $10 \mu \mathrm{L}$ at asymmetric primer ratio. Master mix comprised of 0.6x LCGreen Plus (Idaho Technology Inc., Salt Lake City, UT, USA), $200 \mu \mathrm{M}$ dNTPs (SERVA Electrophoresis $\mathrm{GmbH}$, Heidelberg, Germany), $0.05 \mu \mathrm{M}$ limiting primer, $0.5 \mu \mathrm{M}$ excess primer, $0.5 \mu \mathrm{M}$ probe, $3 \mathrm{mM} \mathrm{MgCl}_{2}$ (SigmaAldrich, Haverhill, UK), 1M betaine (Sigma-Aldrich, Haverhill, UK), 1U BioThermAB polymerase with $1 \mathrm{x}$ corresponding buffer (GeneCraft $\mathrm{GmbH}$, Lüdinghausen, Germany), and approximately 20 ng DNA. PCR conditions were following: initial denaturation at $95{ }^{\circ} \mathrm{C}$ for 5 min, 60 cycles at $95{ }^{\circ} \mathrm{C}$ for $10 \mathrm{~s}, 60{ }^{\circ} \mathrm{C}$ for $15 \mathrm{~s}$ and $72{ }^{\circ} \mathrm{C}$ for $15 \mathrm{~s}$. The sequences of oligonucleotides (SigmaAldrich, Haverhill, UK) were as follows:

For IRF6 rs642961:

5'-GCTTTGGATTGTTAATCTTACCCAAAGG-3 (excess primer),

5'-CTTCCCACCTCCAGGACAGGCAGATG-3" (limiting primer), and 5'ATGTTCACATCCTGGGGTAT TACTT-3“ (probe).

For $8 \mathrm{q} 24$ rs 987525 :

5'-GGTCCTAAGTATACGACACAGGATTTGTTC-3 (limiting primer),

5'TGGTGGAGATGTTTTCACATGAGC-3` (excess primer), and $5^{\circ}$-CTATTTATTTTTTATTTTAGTCTCA AAGTGTG-3‘ (probe).

For 10q25 rs7078160:

5'CCAAGTGGAGCTATGAGAGGTGAG-3“ (excess primer),

5'-CCCATTTCTCGTCTGCCTGACCAG-3' (limiting primer), and $5^{\circ}$-GGGCTCTGAACCCAAGTATCT AT-3“' (probe).
For 17q22 rs227731:

5-CACAGAATAAAATCTAGATAACCTTGAGTAT GG-3“ (limiting primer),

5'-GCCAGCTTATCTGTTACTTATTTCAC-3“ (excess primer), and 5'TTTTAGATACCACACTAAAAGC ATGATCT-3، (probe).

Probes (mismatch-tolerant probes capable of detecting allele-specific targets) were blocked at the 3 -end by phosphate to prevent extension. For all four SNPs the amplification was immediately followed by melting analysis starting with denaturation at $95{ }^{\circ} \mathrm{C}$ for $30 \mathrm{~s}$ and renaturation at $40{ }^{\circ} \mathrm{C}$ for $1 \mathrm{~min}$. Data were acquired over $45-95$ ${ }^{\circ} \mathrm{C}$ range. Genotypes were identified using $\mathrm{Eco}^{\mathrm{TM}}$ Software 4.1 (Illumina, Inc., San Diego, CA, USA) by melting temperatures indicated by probe peaks on derivative plots. Genotyping success rate for all examined variants was $100 \%$. The sequencing on ABI 3500 Genetic Analyzer (Applied Biosystems Inc., Forster City, CA, USA) was used to verify the results of genotyping, with $100 \%$ concordance reached (15 samples for each SNP; 5 samples of each genotype were used). For all SNPs the genotype frequencies were in agreement with those predicted under the conditions of Hardy-Weinberg equilibrium.

\section{Statistical analysis}

Differences in allele distributions between the case and the control groups (Table 1) were analyzed using the two by two table test (http://www.openepi.com; ref. ${ }^{15}$ ). All $P$ values were two-tailed with a significance level of 0.05. For allele distribution Bonferroni correction (multiple comparisons), a corrected $P<0.0125(0.05 / 4)$ was considered statistically significant. Odds Ratio (OR) calculations and $95 \%$ confidence intervals (CIs) were used to estimate the relative risk of $n s C L / P$ by comparing allele and genotype frequencies between cases and controls.

The HWE test, genotype frequencies, and association analysis under different inheritance models (Table 2) were conducted using the web-based association study application program SNPStats (http://bioinfo.iconcologia.net/ SNPstats) $\left(\right.$ ref. $\left.^{16}\right)$. The genetic models tested were as follows: codominant model Dd vs DD and dd vs. DD (d is the minor allele), dominant model dd + Dd vs. DD, recessive model dd vs. Dd + DD and additive model: effect of allele dosage. The aim was to choose the best covariate model for the gene effect. The Bayes information criterion (BIC) (ref. ${ }^{17}$ ) and the Akaike information criterion (AIC) (ref. ${ }^{18}$ ) were used; the smaller AIC and BIC, the better was the model. For evaluation of different genetic models a Bonferroni corrected $P<0.003125(0.05 / 16)$ was considered statistically significant.

\section{RESULTS}

Table 1 shows the results of our association analysis for the allelic distributions and Table 2 for genotype distributions with respect to $\mathrm{nsCL} / \mathrm{P}$ risk.

The allelic frequencies for all the tested SNPs in control group (Table 1) did not differ significantly from an- 
Table 1. Association of SNP allele distribution with nsCL/P and OR estimation in the Slovak population.

\begin{tabular}{llcccc}
\hline Chromosome & SNP & MA & $\begin{array}{c}\text { MAF } \\
\text { Cases /Controls }\end{array}$ & $\begin{array}{c}\text { Odds Ratio }^{\mathrm{a}} \\
(95 \% \text { CI })\end{array}$ & $P$ \\
\hline 1q32 & rs642961 & A & $0.23 / 0.15$ & $1.67(1.20-2.33)$ & $0.002^{*}$ \\
8q24 & rs987525 & A & $0.33 / 0.24$ & $1.56(1.16-2.08)$ & $0.003^{*}$ \\
$10 q 25$ & rs7078160 & A & $0.19 / 0.14$ & $1.39(0.98-1.98)$ & 0.07 \\
$17 q 22$ & rs227731 & C & $0.48 / 0.38$ & $1.49(1.14-1.94)$ & $0.004^{*}$ \\
\hline
\end{tabular}

"Significant $P$-values after Bonferroni correction for multiple testing $(P<0.0125)$.

${ }^{\mathrm{a}}$ Odds Ratio for the minor allele as the target one and the major allele as the reference

nsCL/P, nonsyndromic cleft lip with or without cleft palate; SNP, single nucleotide polymorphism; MA, minor allele;

MAF, minor allele frequency; CI, confidence interval

Table 2. Association of SNP genotype distribution with nsCL/P and OR estimation in the Slovak population.

\begin{tabular}{|c|c|c|c|c|c|c|c|}
\hline Chromosome/ SNP & Model & Genotype & Cases/Controls & $\begin{array}{l}\text { Odds Ratio } \\
(95 \% \text { CI })\end{array}$ & $P$ & $\mathrm{AIC}$ & $\mathrm{BIC}$ \\
\hline \multirow[t]{8}{*}{ 1q32/rs642961 } & \multirow[t]{3}{*}{ Codominant } & GG & $99 / 235$ & 1.00 & \multirow[t]{3}{*}{0.013} & \multirow[t]{3}{*}{624.2} & \multirow[t]{3}{*}{636.7} \\
\hline & & GA & $56 / 83$ & $1.60(1.06-2.42)$ & & & \\
\hline & & $\mathrm{AA}$ & $10 / 8$ & $2.97(1.14-7.74)$ & & & \\
\hline & \multirow[t]{2}{*}{ Dominant } & GG & $99 / 235$ & 1.00 & \multirow[t]{2}{*}{0.007} & \multirow[t]{2}{*}{623.7} & \multirow[t]{2}{*}{632} \\
\hline & & GA-AA & $66 / 91$ & $1.72(1.16-2.55)$ & & & \\
\hline & \multirow[t]{2}{*}{ Recessive } & GG-GA & $155 / 318$ & 1.00 & \multirow[t]{2}{*}{0.05} & \multirow[t]{2}{*}{627.1} & \multirow[t]{2}{*}{635.5} \\
\hline & & AA & $10 / 8$ & $2.56(0.99-6.63)$ & & & \\
\hline & Additive & - & - & $1.65(1.18-2.30)$ & $0.003^{*}$ & 622.2 & 630.6 \\
\hline \multirow[t]{8}{*}{$8 \mathrm{q} 24 / \mathrm{rs} 987525$} & \multirow[t]{3}{*}{ Codominant } & $\mathrm{CC}$ & $79 / 189$ & 1.00 & \multirow[t]{3}{*}{0.009} & \multirow[t]{3}{*}{623.5} & \multirow[t]{3}{*}{636.1} \\
\hline & & $\mathrm{CA}$ & $63 / 117$ & $1.29(0.86-1.93)$ & & & \\
\hline & & AA & $23 / 20$ & $2.75(1.43-5.29)$ & & & \\
\hline & \multirow[t]{2}{*}{ Dominant } & $\mathrm{CC}$ & $79 / 189$ & 1.00 & \multirow[t]{2}{*}{0.03} & \multirow[t]{2}{*}{626.4} & \multirow[t]{2}{*}{634.8} \\
\hline & & CA-AA & $86 / 137$ & $1.50(1.03-2.19)$ & & & \\
\hline & \multirow[t]{2}{*}{ Recessive } & CC-CA & $142 / 306$ & 1.00 & \multirow[t]{2}{*}{0.005} & \multirow[t]{2}{*}{623} & \multirow[t]{2}{*}{631.4} \\
\hline & & AA & $23 / 20$ & $2.48(1.32-4.66)$ & & & \\
\hline & Additive & - & - & $1.51(1.14-2.01)$ & 0.004 & 622.7 & 631.1 \\
\hline \multirow[t]{8}{*}{$10 \mathrm{q} 25 / \mathrm{rs} 7078160$} & \multirow[t]{3}{*}{ Codominant } & GG & $108 / 240$ & 1.00 & \multirow[t]{3}{*}{0.17} & 629.4 & 642 \\
\hline & & GA & $52 / 79$ & $1.46(0.96-2.22)$ & & & \\
\hline & & AA & $5 / 7$ & $1.59(0.49-5.11)$ & & & \\
\hline & Dominant & GG & $108 / 240$ & 1.00 & 0.06 & 627.4 & 635.8 \\
\hline & & GA-AA & $57 / 86$ & $1.47(0.98-2.21)$ & & & \\
\hline & Recessive & GG-GA & $160 / 319$ & 1.00 & 0.56 & 630.5 & 638.9 \\
\hline & & $\mathrm{AA}$ & $5 / 7$ & $1.42(0.44-4.56)$ & & & \\
\hline & Additive & - & - & $1.39(0.98-1.99)$ & 0.07 & 627.6 & 636 \\
\hline 17q22/rs227731 & Codominant & AA & $50 / 129$ & 1.00 & 0.016 & 624.7 & 637.3 \\
\hline & & $\mathrm{AC}$ & $72 / 145$ & $1.28(0.83-1.97)$ & & & \\
\hline & & $\mathrm{CC}$ & $43 / 52$ & $2.13(1.27-3.59)$ & & & \\
\hline & Dominant & $\mathrm{AA}$ & $50 / 129$ & 1.00 & 0.04 & 626.8 & 635.2 \\
\hline & & AC-CC & $115 / 197$ & $1.51(1.01-2.25)$ & & & \\
\hline & Recessive & AA-AC & $122 / 274$ & 1.00 & 0.008 & 623.9 & 632.3 \\
\hline & & $\mathrm{CC}$ & $43 / 52$ & $1.86(1.18-2.93)$ & & & \\
\hline & Additive & - & - & $1.44(1.11-1.87)$ & 0.005 & 623.1 & 631.5 \\
\hline
\end{tabular}

*Significant $P$-values after Bonferroni correction for multiple testing $(P<0.003125)$.

The Bayes information criterion (BIC) and the Akaike information criterion (AIC) - the smaller AIC and BIC, the more relevant model nsCL/P, nonsyndromic cleft lip with or without cleft palate; SNP, single nucleotide polymorphism; CI, confidence interval

other publicly available data on Caucasian populations (http://www.ensembl.org) and were also similar to the frequencies reported from other case-control studies conducted on Central European populations ${ }^{10,12,19,20}$. With respect to allele distributions, the significant associations with nsCL/P risk, persisting even after Bonferroni correc- tion for multiple comparisons, were found for SNPs at the 1q32, 8q24 and 17q22 loci. Regarding genotype distributions, significant association was similarly observed for SNPs at the 1q32, 8q24 and 17q22 loci for all the tested genetic models. We found that in the additive model, the association of rs642961 at 1q32 with nsCL/P risk sur- 
vived the correction for multiple comparisons (Table 2). SNP rs7078160 at the 10q25 locus reached borderline significance, manifesting a trend toward association with nsCL/P susceptibility in the Slovak population (Table 1 and 2). The alleles associated with an increased risk of nsCL/P in this study (allele A in rs642961, A in rs987525, $A$ in rs7078160, and $C$ in rs227731) corresponded to the risk alleles identified in previous investigations.

\section{DISCUSSION}

In the present study, a selection representing the four significant SNPs identified by previous GWAS was examined for an association with nsCL/P in an independent sample of the Slovak population.

The first conclusively identified genetic risk factor for orofacial clefts was the interferon regulatory factor 6 (IRF6) gene located at chromosomal region 1q32 (ref. ${ }^{7}$ ). Subsequent analyses identified a causative variant rs642961 in the IRF6 promoter region which disrupts the binding site of the transcription factor AP-2a involved in craniofacial development ${ }^{8}$. In this report, we found that rs642961 was associated with nsCL/P risk in all of the models of inheritance tested, with a 1.6 to almost a threefold increase in risk. The most significant results, persisting after Bonferroni correction, were observed when the additive model was used, confirming dosage risk effect of minor allele A. Positive association between the IRF6 rs642961 variant and $\mathrm{nsCL} / \mathrm{P}$ has been confirmed by multiple studies involving various ethnicities ${ }^{21-24}$. Also, our results are in accordance with the findings from two case-control studies on Central European populations which showed similar magnitudes of odds ratios ${ }^{10,19}$. Nonetheless, one European and two non-European studies did not identify any association between this variant and $\mathrm{nsCL} / \mathrm{P}\left(\right.$ ref. $\left.^{25-27}\right)$.

Another finding of our study was an association of the SNP located at the 8q24 locus with nsCL/P. The rs 987525 showed nominal significance in all of the models of inheritance tested, with a 1.5 to more than twofold increase in risk. Similar results for rs 987525 were obtained in a study on the Central European sample which showed a 1.7fold increase in the risk of $n s C L / P$ under the dominant inheritance mode ${ }^{19}$. Although the association between rs987525 and the risk of $n s C L / P$ has been replicated in numerous studies on various ethnicities ${ }^{28-31}$, the underlying functional mechanism remains unknown as rs 987525 resides in a region of the genome containing no known genes $^{12}$. It is possible that rs987525 or a linked causal SNP affects tissue-specific enhancers, altering the expression of one or more unspecified genes. Known genes mapped to the area near the $8 \mathrm{q} 24$ gene desert include $M Y C$ and $G S D M C$, encoding myc proto-oncogene protein, and melanoma-derived leucine zipper-containing extranuclear factor, respectively. A recent study of murine embryos found that the orthologous $280-\mathrm{kb}$ region adjacent to human rs987525 harboured potential craniofacial enhancer elements, suggesting the presence of a regulatory effect ${ }^{32}$.
For the variant rs227731 at 17q22 locus, in the present sample we found a significant association with $\mathrm{nsCL} / \mathrm{P}$ in all of the genetic models tested, with the OR values ranging from 1.4 to 2.1. Similar values were reported from a study by Mostowska et al. ${ }^{20}$ on another Central European (Polish) population. Evidence for the involvement of this locus in the $\mathrm{nsCL} / \mathrm{P}$ aetiology was originally reported by GWAS of Mangold et al. ${ }^{14}$ in the European-derived population. However, the subsequent replication studies conducted in the Mesoamerican, Italian, Chinese Han and Kenyan populations did not confirm these positive results $^{21,31,33,34}$. The nucleotide variant rs227731 is located $100 \mathrm{~kb}$ centromeric of the NOG gene. NOG acts as antagonist of members of the TGF-b superfamily, which have been implicated in orofacial clefting ${ }^{35}$. Recently, Leslie et al. ${ }^{36}$ identified a common causative variant rs227727 near the NOG gene, which leads to disruption of its enhancer activity. This SNP was in complete linkage disequilibrium with rs227731.

Finally, the remaining tested SNP rs7078160 at the 10q25 locus approached significance, manifesting only a trend toward association with nsCL/P susceptibility in the Slovak population. SNP rs 7078160 is intergenic, located near the $V A X 1$ gene encoding a transcriptional regulator with a DNA-binding homeobox domain. An association between rs7078160 and nsCL/P has been replicated in several studies, which included European and Mesoamerican samples $^{20,21,37}$, but Chinese and Kenyan studies ${ }^{33,34}$ have reported contradictory results. A meta-analysis of 7 eligible studies $^{38}$ showed only a modest association of rs 7078160 with nsCL/P risk. This also revealed that the magnitudes of the associations varied among the white, the Asian, and mixed populations, which may suggest that ethnic heterogeneity and environmental factors may have different impacts with respect to the association between $10 \mathrm{q} 25$ rs 7078160 and the risk of nsCL/P.

\section{CONCLUSION}

Genetic studies of complex traits in populations are important, both to define common and population-specific risk alleles, and also to understand the underlying biology $^{6}$. Recent studies have reported association of nsCL/P with many loci throughout the genome $\mathrm{e}^{11-14,39-42}$. Replication of those results on various populations and the investigation of mechanisms by which these variants influence cleft susceptibility are crucial for better understanding of genetic architecture of nsCL/P.

The present study replicated nsCL/P risk loci 1q32, $8 \mathrm{q} 24$, and $17 \mathrm{q} 22$ in a new population. It also suggested that the 10q25 locus might be implicated in the risk of $\mathrm{nsCL} / \mathrm{P}$ in the Slovak population, although it failed to reach significance. The study, however, has some limitations such as a relatively small sample size in the case group resulting in limited statistical power, and a lack of the data related to potential environmental risk factors. Further studies on various populations are needed to replicate GWAS results to identify population-specific 
nsCL/P genes/loci, as well as to find etiologic nucleotide variants and biologic mechanisms conferring susceptibility to orofacial clefts.

Acknowledgement: We wish to acknowledge the particular assistance of Dr. Dagmar Fekiacova in the collection of patient samples in Bratislava.

The study was supported by the grant VEGA 1/0312/14 of the Ministry of Education of the Slovak Republic (50\%) and the project SEPO II, Operational Program Research and Development financed by European Fund for Regional Development, ITMS: 26220120039 (50\%). Author contributions: JS, LK: study design, sample and data collection, data interpretation, statistical analysis, manuscript writing and literature search; MZ, JB, TH, JF, AM, LP: sample and data collection, data interpretation. Conflict of interest statement: The authors state that there are no conflicts of interest regarding the publication of this article.

\section{REFERENCES}

1. Vanderas AP. Incidence of cleft lip, cleft palate and cleft lip and palate among races: A review. Cleft Palate J 1987;24:216-25.

2. Croen LA, Shaw GM, Wasserman CR, Tolarova MM. Racial and ethnic variations in the prevalence of orofacial clefts in California, 19831992. Am J Med Genet 1998;79:42-7.

3. Mossey PA, Little J. Epidemiology of oral clefts: An international perspective. In: Wyszynski DF, editor. Cleft lip and palate. From origins to treatment. Oxford: Oxford University Press 2002;127-58.

4. Gundlach KK, Maus C. Epidemiological studies on the frequency of clefts in Europe and world-wide. J Craniomaxillofac Surg 2006;34:1 2.

5. Wehby GL, Cassell CH. The impact of orofacial clefts on quality of life and healthcare use and costs. Oral Dis 2010;16:3-10.

6. Dixon MJ, Marazita ML, Beaty TH, Murray JC. Cleft lip and palate: understanding genetic and environmental influences. Nat Rev Genet 2011;12:167-78.

7. Zucchero TM, Cooper ME, Maher BS, Daack-Hirsch S, Nepomuceno B, Ribeiro L, Caprau D, Christensen K, Suzuki Y, Machida J, Natsume $\mathrm{N}$, Yoshiura K, Vieira AR, Orioli IM, Castilla EE, Moreno L, Arcos-Burgos M, Lidral AC, Field LL, Liu YE, Ray A, Goldstein TH, Schultz RE, Shi M, Johnson MK, Kondo S, Schutte BC, Marazita ML, Murray JC. Interferon regulatory factor 6 (IRF6) gene variants and the risk of isolated cleft lip or palate. N Engl J Med 2004,351:768-9.

8. Rahimov F, Marazita ML, Visel A, Cooper ME, Hitchler MJ, Rubini M, Domann FE, Govil M, Christensen K, Bille C, Melbye M, Jugessur A, Lie RT, Wilcox AJ, Fitzpatrick DR, Green ED, Mossey PA, Little J, SteegersTheunissen RP, Pennacchio LA, Schutte BC, Murray JC. Disruption of an AP-2alpha binding site in an IRF6 enhancer is associated with cleft lip. Nat Genet 2008;40:1341-7.

9. Park JW, McIntosh I, Hetmanski JB, Jabs EW, Vander Kolk CA, WuChou YH, Chen PK, Chong SS, Yeow V, Jee SH, Park BY, Fallin MD, Ingersoll R, Scott AF, Beaty TH. Association between IRF6 and nonsyndromic cleft lip with or without cleft palate in four populations. Genet Med 2007;9:219-27.

10. Birnbaum $S$, Ludwig KU, Reutter $H$, Herms $S$, de Assis NA, DiazLacava A, Barth S, Lauster C, Schmidt G, Scheer M, Saffar M, Martin M, Reich RH, Schiefke F, Hemprich A, Pötzsch S, Pötzsch B, Wienker TF, Hoffmann P, Knapp M, Kramer FJ, Nöthen MM, Mangold E. IRF6 gene variants in Central European patients with non-syndromic cleft lip with or without cleft palate. Eur J Oral Sci 2009a;117:766-9.

11. Beaty TH, Murray JC, Marazita ML, Munger RG, Ruczinski I, Hetmanski JB, Liang KY, Wu T, Murray T, Fallin MD, Redett RA, Raymond G, Schwender H, Jin SC, Cooper ME, Dunnwald M, Mansilla MA, Leslie E, Bullard S, Lidral AC, Moreno LM, Menezes R, Vieira AR, Petrin A, Wilcox AJ, Lie RT, Jabs EW, Wu-Chou YH, Chen PK, Wang H, Ye X, Huang S, Yeow V, Chong SS, Jee SH, Shi B, Christensen K, Melbye M,
Doheny KF, Pugh EW, Ling H, Castilla EE, Czeizel AE, Ma L, Field LL, Brody L, Pangilinan F, Mills JL, Molloy AM, Kirke PN, Scott JM, ArcosBurgos M, Scott AF. A genome-wide association study of cleft lip with and without cleft palate identifies risk variants near MAFB and ABCA4. Nat Genet 2010;42:525-9.

12. Birnbaum S, Ludwig KU, Reutter $H$, Herms $S$, Steffens $M$, Rubin M, Baluardo C, Ferrian M, Almeida de Assis N, Alblas MA, Barth S, Freudenberg J, Lauster C, Schmidt G, Scheer M, Braumann B, Berge SJ, Reich RH, Schiefke F, Hemprich A, Potzsch S, Steegers-Theunissen RP, Potzsch B, Moebus S, Horsthemke B, Kramer FJ, Wienker TF, Mossey PA, Propping P, Cichon S, Hoffmann P, Knapp M, Nothen MM, Mangold E. Key susceptibility locus for nonsyndromic cleft lip with or without cleft palate on chromosome 8q24. Nat Genet 2009b;41:473-7.

13. Grant SF, Wang K, Zhang H, Glaberson W, Annaiah K, Kim CE, Bradfield JP, Glessner JT, Thomas KA, Garris M, Frackelton EC, Otieno FG, Chiavacci RM, Nah HD, Kirschner RE, Hakonarson H. A genomewide association study identifies a locus for nonsyndromic cleft lip with or without cleft palate on 8q24. J Pediatr 2009;155:909-13.

14. Mangold E, Ludwig KU, Birnbaum S, Baluardo C, Ferrian M, Herms S, Reutter $\mathrm{H}$, de Assis NA, Chawa TA, Mattheisen M, Steffens M, Barth S, Kluck N, Paul A, Becker J, Lauster C, Schmidt G, Braumann B, Scheer M, Reich RH, Hemprich A, Potzsch S, Blaumeiser B, Moebus S, Krawczak M, Schreiber S, Meitinger T, Wichmann HE, SteegersTheunissen RP, Kramer FJ, Cichon S, Propping P, Wienker TF, Knapp M, Rubini M, Mossey PA, Hoffmann P, Nothen MM. Genome-wide association study identifies two susceptibility loci for nonsyndromic cleft lip with or without cleft palate. Nat Genet 2010;42:24-6.

15. Dean AG, Sullivan KM, Soe MM. OpenEpi: Open Source Epidemiologic Statistics for Public Health, Version. www.OpenEpi.com, updated 2015/05/04.

16. Sole X, Guino E, Valls J, Iniesta R, and Moreno V. SNPStats: a web tool for the analysis of association studies. Bioinformatics 2006;22:19289.

17. Schwarz G. Estimating the Dimension of a Model. Ann Stat 1978;6:461-4.

18. Akaike H. A new look at the statistical model identification. Trans Autom Control 1974;19:716-23.

19. Mostowska A, Hozyasz KK, Wojcicki P, Biedziak B, Paradowska P, Jagodzinski PP. Association between genetic variants of reported candidate genes or regions and risk of cleft lip with or without cleft palate in the Polish population. Birth Defects Res A Clin Mol Teratol 2010;88:538-45.

20. Mostowska A, Hozyasz KK, Wojcicka K, Biedziak B, Jagodzinski PP. Polymorphic Variants at 10q25.3 and 17q22 Loci and the Risk of Non-syndromic Cleft Lip and Palate in the Polish Population. Birth Defects Res A Clin Mol Teratol 2012;94:42-6.

21. Rojas-Martinez $A$, Reutter $H$, Chacon-Camacho $O$, Leon-Cachon RB, Munoz-Jimenez SG, Nowak S, Becker J, Herberz R, Ludwig KU, Paredes-Zenteno M, Arizpe-Cantú A, Raeder S, Herms S, Ortiz-Lopez R, Knapp M, Hoffmann P, Nöthen MM, Mangold E. Genetic risk factors for nonsyndromic cleft lip with or without cleft palate in a Mesoamerican population: evidence for IRF6 and variants at 8q24 and 10q25. Birth Defects Res A Clin Mol Teratol 2010;88:535-7.

22. Pan Y, Ma J, Zhang W, Du Y, Niu Y, Wang M, Zhang Z, Wang L. IRF6 polymorphisms are associated with nonsyndromic orofacial clefts in a Chinese Han population. Am J Med Genet A 2010;152A:2505-11.

23. Shi J, Song T, Jiao X, Qin C, Zhou J. Single-nucleotide polymorphisms (SNPs) of the IRF6 and TFAP2A in non-syndromic cleft lip with or without cleft palate (NSCLP) in a northern Chinese population. Biochem Biophys Res Commun 2011;410:732-6.

24. Brito LA, Bassi CF, Masotti C, Malcher C, Rocha KM, Schlesinger D, Bueno DF, Cruz LA, Barbara LK, Bertola DR, Meyer D, Franco D, Alonso N, Passos-Bueno MR. IRF6 is a Risk Factor for Nonsyndromic Cleft Lip in the Brazilian Population. Am J Med Genet A 2012a;158A:2170-5.

25. Paranaíba LM, Bufalino A, Martelli-Júnior $H$, de Barros LM, Graner E, Coletta RD. Lack of association between IRF6 polymorphisms (rs2235371 and rs642961) and non-syndromic cleft lip and/or palate in a Brazilian population. Oral Dis 2010;16:193-7.

26. Larrabee YC, Birkeland AC, Kent DT, Flores C, Su GH, Lee JH, Haddad $\mathrm{J} \mathrm{Jr}$. Association of common variants, not rare mutations, in IRF6 with nonsyndromic clefts in a Honduran population. Laryngoscope 2011;121:1756-9.

27. Pegelow $M$, Koillinen $\mathrm{H}$, Magnusson $M$, Fransson I, Unneberg P, Kere J, Karsten A, Peyrard-Janvid M. Association and mutation analyses 
of the IRF6 gene in families with nonsyndromic and syndromic cleft lip and/or cleft palate. Cleft Palate Craniofac J 2014;51:49-55.

28. Nikopensius T, Ambrozaityte L, Ludwig KU, Birnbaum S, Jagomägi T, Saag M, Matuleviciene A, Linkeviciene L, Herms S, Knapp M, Hoffmann P, Nöthen MM, Kucinskas V, Metspalu A, Mangold E. Replication of novel susceptibility locus for nonsyndromic cleft lip with or without cleft palate on chromosome 8q24 in Estonian and Lithuanian patients. Am J Med Genet A 2009;149A:2551-3.

29. Brito LA, Paranaiba LM, Bassi CF, Masotti $C$, Malcher C, Schlesinger D, Rocha KM, Cruz LA, Bárbara LK, Alonso N, Franco D, Bagordakis E, Martelli H Jr, Meyer D, Coletta RD, Passos-Bueno MR. Region 8q24 is a susceptibility locus for nonsyndromic oral clefting in Brazil. Birth Defects Res A Clin Mol Teratol 2012b;94:464-8.

30. do Rego Borges A, Sá J, Hoshi R, Viena CS, Mariano LC, de Castro Veiga P, Medrado AP, Machado RA, de Aquino SN, Messetti AC, Spritz RA, Coletta RD, Reis SR. Genetic risk factors for nonsyndromic cleft lip with or without cleft palate in a Brazilian population with high African ancestry. Am J Med Genet A 2015;167A:2344-9.

31. Cura F, Böhmer AC, Klamt J, Schünke $H$, Scapoli L, Martinelli $M$, Carinci F, Nöthen MM, Knapp M, Ludwig KU, Mangold E. Replication analysis of 15 susceptibility loci for nonsyndromic cleft lip with or without cleft palate in an Italian population. Birth Defects Res A Clin Mol Teratol 2016;106:81-7.

32. Uslu VV, Petretich M, Ruf S, Langenfeld K, Fonseca NA, Marioni JC, Spitz F. Long-range enhancers regulating Myc expression are required for normal facial morphogenesis. Nat Genet 2014;46:753-8.

33. Pan $Y$, Ma J, Zhang W, Wang $Y$, Wang $Y$, Zhang $H$, Wang $M$, Zhang Z, Wang L. Replication of two novel susceptibility loci for non-syndromic orofacial clefts in a Chinese population. Oral Dis 2011;17:304-8.

34. Weatherley-White RC, Ben S, Jin Y, Riccardi S, Arnold TD, Spritz RA. Analysis of genome-wide association signals for nonsyndromic cleft lip/palate in a Kenya African Cohort. Am J Med Genet A 2011;155A:2422-5.

35. Suzuki S, Marazita ML, Cooper ME, Miwa N, Hing A, Jugessur A Natsume N, Shimozato K, Ohbayashi N, Suzuki Y, Niimi T, Minami K, Yamamoto M, Altannamar TJ, Erkhembaatar T, Furukawa H, DaackHirsch S, L'heureux J, Brandon CA, Weinberg SM, Neiswanger K, Deleyiannis FW, de Salamanca JE, Vieira AR, Lidral AC, Martin JF, Murray JC. Mutations in BMP4 are associated with subepithelial, microform, and overt cleft lip. Am J Hum Genet 2009;84:406-11.

36. Leslie EJ, Taub MA, Liu H, Steinberg KM, Koboldt DC, Zhang Q, Carlson JC, Hetmanski JB, Wang H, Larson DE, Fulton RS, Kousa YA, Fakhouri WD, Naji A, Ruczinski I, Begum F, Parker MM, Busch T, Standley J, Rigdon J, Hecht JT, Scott AF, Wehby GL, Christensen K, Czeizel AE, Deleyiannis FW, Schutte BC, Wilson RK, Cornell RA, Lidral
AC, Weinstock GM, Beaty TH, Marazita ML, Murray JC. Identification of functional variants for cleft lip with or without cleft palate in or near PAX7, FGFR2, and NOG by targeted sequencing of GWAS loci. Am J Hum Genet 2015;96:397-411.

37. Nikopensius T, Birnbaum S, Ludwig KU, Jagomägi T, Saag M, Herms S, Knapp M, Hoffmann P, Nöthen MM, Metspalu A, Mangold E. Susceptibility locus for non-syndromic cleft lip with or without cleft palate on chromosome 10q25 confers risk in Estonian patients. Eur J Oral Sci 2010;118:317-9.

38. Li C, Li Z, Zeng X, Guo Z. Is a polymorphism in 10q25 associated with non-syndromic cleft lip with or without cleft palate? A meta-analysis based on limited evidence. Br J Oral Maxillofac Surg 2015;53:8-12.

39. Ludwig KU, Mangold E, Herms S, Nowak S, Reutter H, Paul A, Becker $J$, Herberz R, AlChawa T, Nasser E, Bohmer AC, Mattheisen M, Alblas MA, Barth S, Kluck N, Lauster C, Braumann B, Reich RH, Hemprich A, Potzsch S, Blaumeiser B, Daratsianos N, Kreusch T, Murray JC, Marazita ML, Ruczinski I, Scott AF, Beaty TH, Kramer FJ, Wienker TF, Steegers-Theunissen RP, Rubini M, Mossey PA, Hoffmann P, Lange C, Cichon S, Propping P, Knapp M, Nothen MM. Genome-wide metaanalyses of nonsyndromic cleft lip with or without cleft palate identify six new risk loci. Nat Genet 2012;44:968-71.

40. Beaty TH, Taub MA, Scott AF, Murray JC, Marazita ML, Schwender H, Parker MM, Hetmanski JB, Balakrishnan P, Mansilla MA, Mangold E, Ludwig KU, Noethen MM, Rubini M, Elcioglu N, Ruczinski I. Confirming genes influencing risk to cleft lip with/without cleft palate in a case-parent trio study. Hum Genet 2013;132:771-81.

41. Sun $Y$, Huang $Y$, Yin $A$, Pan $Y$, Wang $Y$, Wang $C$, Du $Y$, Wang $M$, Lan $F$, Hu Z, Wang G, Jiang M, Ma J, Zhang X, Ma H, Ma J, Zhang W, Huang Q, Zhou Z, Ma L, Li Y, Jiang H, Xie L, Jiang Y, Shi B, Cheng J, Shen $\mathrm{H}_{\text {, }}$ Wang L, Yang Y. Genome-wide association study identifies a new susceptibility locus for cleft lip with or without a cleft palate. Nat Commun 2015;6:6414.

42. Leslie EJ, Carlson JC, Shaffer JR, Feingold E, Wehby G, Laurie CA, Jain D, Laurie CC, Doheny KF, McHenry T, Resick J, Sanchez C, Jacobs J, Emanuele B, Vieira AR, Neiswanger K, Lidral AC, Valencia-Ramirez LC, Lopez-Palacio AM, Valencia DR, Arcos-Burgos M, Czeizel AE, Field LL, Padilla CD, Cutiongco-de la Paz EM, Deleyiannis F, Christensen K, Munger RG, Lie RT, Wilcox A, Romitti PA, Castilla EE, Mereb JC, Poletta FA, Orioli IM, Carvalho FM, Hecht JT, Blanton SH, Buxo CJ, Butali A, Mossey PA, Adeyemo WL, James O, Braimah RO, Aregbesola BS, Eshete MA, Abate F, Koruyucu M, Seymen F, Ma L, de Salamanca JE, Weinberg SM, Moreno L, Murray JC, Marazita ML. A multi-ethnic genome-wide association study identifies novel loci for non-syndromic cleft lip with or without cleft palate on 2p24.2, 17q23 and 19q13. Hum Mol Genet 2016;25:2862-72. 